\title{
DISKURSUS IDENTITAS PEREMPUAN DALAM MAJALAH PEREMPUAN MUSLIM INDONESIA
}

\author{
Nisa Kurnia Illahiati \\ Departemen Komunikasi Fakultas Ilmu Sosial dan Ilmu Politik Universitas Airlangga
}

\begin{abstract}
This study aims to critically analyze the female identity discourse articulated by the Indonesian Muslim Women's magazine. Preceded by the emergence of a significant problem during the process of modernization, Indonesia has experienced the transformation of religious values from ideology toward commercialization of spirituality reflected in their lifestyle. The constellation of media discourse creates a meaning transformation on how identity is performed and how a Moslem is in contemporary Indonesia. This study applies a discourse analysis perspective by Michael Foucault. The data were gathered from a collection of visual and textual discourse obtained from three Moslem women's magazine, Alia, Ummi and Noor. The data analyzed include pictures, words, and phrases as a marker of female identity as a Moslem. The results of this study indicate that the female identity as a Moslem in Indonesia is not an absolute thing. Even though the teaching is from the same scripture, the interpretation of female identity, its nature and its realm becomes plural as there was a lot of discussion and arguments.
\end{abstract}

Keywords: discourse, Moslem women, identity, magazine, contemporary Indonesia

\begin{abstract}
Abstrak: Penelitian ini bertujuan mengetahui identitas perempuan yang diartikulasikan oleh majalah perempuan muslim Indonesia. Metode yang digunakan adalah analisis wacana menggunakan perspektif formasi diskursif milik Michel Foucault. Data berupa visual maupun teks yang diperoleh dari tiga majalah perempuan muslim, yaitu Alia, Ummi dan Noor. Unit analisis dalam penelitian adalah gambar, kata, frasa. Hasil penelitian menunjukkan bahwa identitas perempuan (muslim) Indonesia bukanlah suatu hal yang tunggal . Walaupun secara dogma diangkat dari kitab suci yang sama, namun tafsiran terhadap pengartikulasikan identitas perempuan beserta kodrat dan ranah yang mengikutinya menjadi plural, saling berdiskusi bahkan saling mendebat.
\end{abstract}

Kata Kunci: Diskursus, Perempuan Muslim, Identitas, Majalah, Indonesia Kontemporer

Salah satu persoalan yang cukup signifikan dalam proses modernisasi Indonesia adalah transformasi beragama dari ideologisasi menuju komersialisasi spiritualitas yang disimbolkan oleh gaya hidup (Ibrahim, 2007:155-158). Semenjak Orde Baru berakhir, 
identitas perempuan muslim menjadi salah satu identitas perempuan yang dipopulerkan oleh media massa Indonesia untuk menunjukkan simbolisasi kesalehan kelas menengah (Ibrahim, 2007:151). Media dengan konstelasi diskursusnya menciptakan sebuah makna tampilan muslimah dalam kondisi Indonesia kontemporer. Kecenderungan ini menimbulkan sebuah reproduksi identitas keislaman yang memiliki modifikasi dibandingkan dengan kondisi keislaman pada masa Orde Baru.

Pada lanskap Indonesia kontemporer, identitas keislaman bukan lagi mejadi hal yang tabu. Seiring dengan materialisme yang tumbuh di kalangan masyarakat Indonesia serta komodifikasi yang terus diresonansikan oleh media massa, media menciptakan sebuah budaya Islam pop yang mengunggulkan performativitas dalam beragama Islam sendiri kini tidak hanya dilihat dari level-level simbolik yang diyakini sebagai artefak keislaman, melainkan diwujudkan dalam bentuk budaya pop yang kemudian diadaptasi sebagai gaya hidup kaum muslim Indonesia (Ibrahim, 2007:134). Tumbuhnya sekolah-sekolah Islam dengan biaya yang mahal, fashion dengan label Exclusive Moslem Fashion menjadi salah satu indikator kebangkitan "Islam" yang dikategorisasikan sebagai budaya pop. Begitu juga dengan media massa.

Penerbitan dengan menonjolkan identitas keislaman dan isinya diambilkan dari kitab suci bermunculan. Penerbitan ini segmentasinya terbatas, akan tetapi dapat digunakan sebagai representasi kebangkitan penerbitan "Islam". Misalnya munculnya majalah-majalah Islam seperti Noor, Alia dan Paras yang masing-masing memiliki segmentasi dan konstelasi identitas keislaman tersendiri. Setiap konten media dengan label Islam, merambat kepada produk-produk media lainnya, misalnya pada majalah perempuan. Isi majalah pada akhirnya turut mengkonstruksi identitas Islam kontemporer yang tidak konservatif serta tetap gaul dan trendi (Ibrahim, 2007:135). Kaum feminis menganggap majalah menempati posisi penting, karena mereka memiliki kekuatan untuk menentukan dan membangun feminitas perempuan (Hollows, 2000: 216). Perempuan yang merepresentasikan femininity culture lantas menjadi manifestasi nyata dari perdebatan yang tengah berlangsung terkait dengan transformasi nilainilai dalam masyarakat. Itu sebabnya, kajian budaya sering menjelajahi bagaimana culture menghasilkan, mereproduksi, atau bahkan mendekonstruksi praktik-praktik budaya yang telah tertanam dan dianggap taken for granted menjadi lebih progresif dalam kerangka subkultur. Praktik ini lantas terefleksikan dalam konten media yang mengeksplorasi kehidupan sehari-hari perempuan.

Identitas merupakan salah satu lokus produk yang dihasilkan oleh budaya media (Kellner, 1995). Karenanya, dapat disimpulkan bahwa budaya yang dimunculkan di majalah merupakan produk yang dihasilkan oleh institusi media yang pada dasarnya merupakan bagian dari komunitas masyarakat itu sendiri. Majalah sebagai media massa, budaya serta komunitas sebagai masyarakat lantas menjadi tiga hal yang berkorelasi dan saling berimplikasi (McQuail, 2000: 61). Majalah kemudian menjadi produk kultural yang memanifestasikan gagasan-gagasan masyarakat mengenai suatu realita yang tercermin melalui objek sosial. Sehingga, objek ini tidak harus ditampilkan apa adanya, melainkan ditransformasi dalam bentuk realitas imajiner sebagai hasil dari produk konstruksi yang dilakukan oleh para produser teks. Bahasa populer yang biasa digunakan untuk menyebut realitas hasil konstruksi media ini adalah representasi. Menurut Hall (2002, 15), "representation is an activity that uses the language of communication that have specific meanings as defined in socio-cultural context to describe, represent, or re-present an object (or reality)". Jadi, proses representasi pada dasarnya merupakan proses rekonstruksi realita melalui bahasa dan strukturnya yang memiliki makna konsensual. 
Sebagai sebuah produk budaya, eksistensi majalah tidak akan pernah lepas dari institusi yang memproduksinya (Strinati, 2007: 5). Institusi ini tentunya merupakan bagian dari masyarakat yang memiliki seperangkat nilai-nilai yang diyakini sebagai warisan para leluhurnya dalam bentuk budaya. Representasi yang mereka produksi di majalah sedikit banyak akan mencerminkan ideologi mereka terkait dengan kondisi suatu masyarakat yang ideal. Praktik-praktik diskursif ini pada akhirnya memproduksi, mereproduksi atau bahkan melanggengkan sebuah diskursus yang mendukung sebuah kekuatan dominan yang memproduksi 'common sense' bagi masyarakat yang mengonsumsinya.

Berdasar argumen tersebut, dapat diinterpretasi bahwa majalah mempresentasikan realitas simbolik yang didasarkan pada representasi faktual dari realitas yang tengah beroperasi dalam lingkungan sosial. Seperti yang disampaikan oleh Fiske (1996: 53-56) "symbolic reality is produced through symbolic interactions formed by the language and conventions (consensual meaning)". Artinya, penggunaan bahasa yang digunakan untuk merepresentasikan realita memiliki sifat bias dan tidak bebas nilai, sehingga dalam setiap pemilihan bahasa yang akan digunakan selalu melibatkan makna-makna laten terkait nilainilai yang melekat pada penggunaan bahasa. Penggunaan bahasa dipahami dalam konteks tidak hanya terbatas pada kata-kata, tetapi juga pada atribut, gesture, serta angle artikel, plot hingga tata letak (McLaughlin, 2000: 8). Sehingga, pada dasarnya realitas simbolik yang ada di majalah menawarkan nilai-nilai tertentu kepada khalayak mengenai kondisi masyarakat yang dianggap ideal. Atas dasar paparan di atas, maka penelitian ini bertujuan untuk mengetahui bagaimana wacana identitas perempuan dikonstruksi dalam majalah-majalah Islam.

\section{METODE}

Penelitian ini menggunakan metode formasi diskursif dari Faucoult dengan memfokuskan pada teks-teks yang mengartikulasikan identitas yang ditawarkan majalah kepada khalayak pembacanya (Foucault, 2012:106). Menggunakan kerangka analisis diskursus, penelitian ini akan menghubungkan makna inheren teks dengan kondisi sosiokultural terkait diskursus Muslim di Indonesia (Mudhoffir, 2013).

Penelitian ini menggunakan tiga majalah sebagai sumber data yang diasumsikan mengartikulasikan dasar ideologinya yang berafiliasi dengan kelompok keislamannya masing-masing. Majalah Aulia, Ummi, dan Noor. Data yang digunakan berupa teks dalam bentuk tertulis maupun gambar. Unit analisis yang digunakan dalam riset ini termasuk gambar, kata, frasa, pada dasarnya setiap tanda yang menjadi petanda identitas perempuan (muslim) melalui penandanya.

Teknik pengumpulan data dengan cara menyeleksi diskursus mengenai identitas perempuan (muslim) yang berusaha diartikulasikan oleh tiap-tiap majalah tersebut. Artinya, teks apapun yang memuat pesan mengenai formasi diskursif identitas perempuan muslim masuk dalam proses seleksi data. Teknik analisis data dimulai setelah proses seleksi data, berupa interpretasi menggunakan kerangka analisis diskursif, utamanya formasi diskursif yang menunjukkan konstelasi diskursus yang beroperasi di tengah-tengah sistem penandaan tersebut. Selanjutnya, formasi diskursif ini akan dikontekskan pada kondisi riil sosio-kultural Indonesia melalui relasinya dengan penanda lain (intertekstualitas). 


\section{HASIL DAN PEMBAHASAN}

\section{Narasi Visual Sampul Depan}

Pada bagian ini dibahas mengenai narasi visual yang muncul dari sampul depan majalah yang digunakan sebagai sumber data. Majalah Ummi yang dijadikan sumber data menggambarkan identitas perempuan pada gambar 1 .
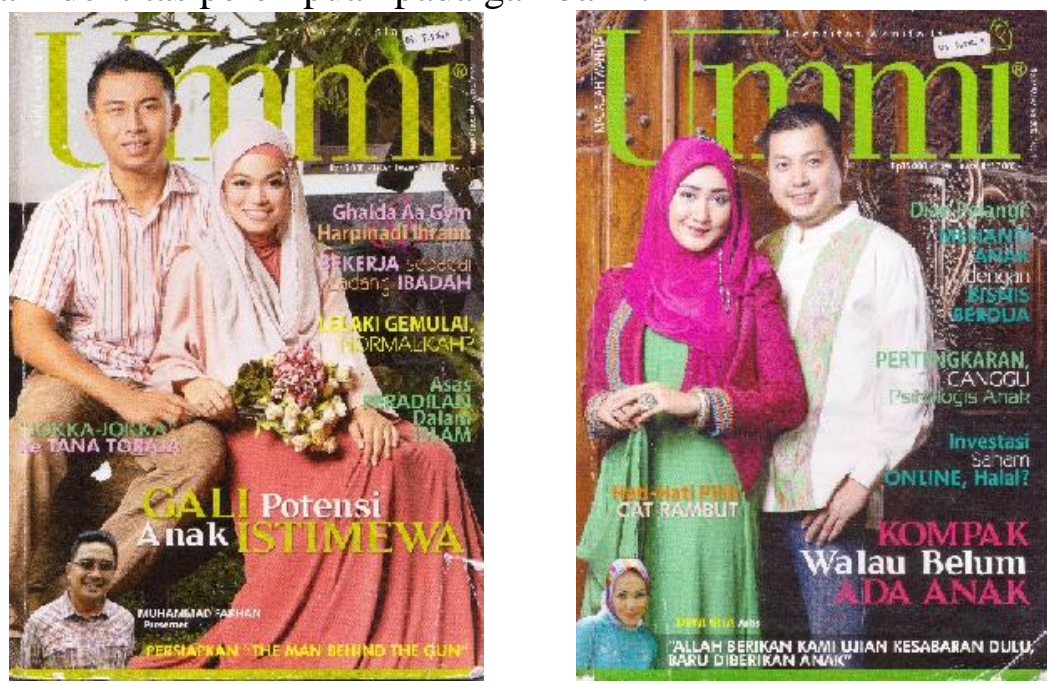

Gambar 1. Sampul Depan Majalah Ummi

Sumber: Ummi No.4/XXXIV/April2012/1439H dan Ummi No.5/XXIV/Mei2012/1433H

Perempuan pada sampul depan majalah Ummi digambarkan bersama dengan sosok lelaki. Di dalam majalah lantas dijelaskan bahwa model yang digunakan sebagai figur sampul depan merupakan mukhrim dengan hubungan suami-istri. Majalah yang mengusung tagline Identitas Wanita Islam ini meneguhkan diskursus Islam dominan di Indonesia mengenai identitas perempuan yang selalu dikaitkan dengan suaminya.

Sementara itu, Aulia yang mengusung Tagline Inspirasi Wanita Mulia, merepresentasikan identitas perempuan melalui sampul depannya sebagaimana pada gambar 2 . 

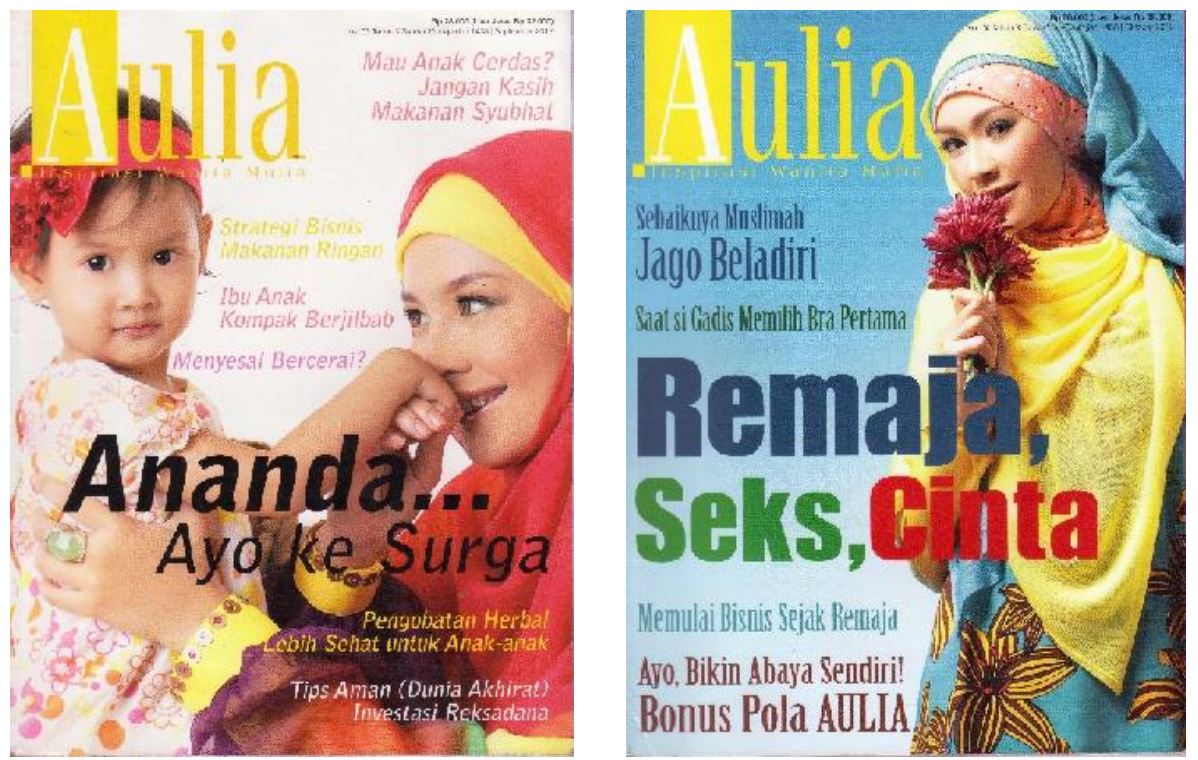

Gambar 2. Sampul Depan Majalah Aulia

Sumber: Aulia No.03Tahun X Syawal-Dulqo'dah 1433/September 2012 dan Aulia No.04 Tahun X Dzulqa'dah-Dzulhijjah 1433/Oktober2012

Sampul depan Aulia No. 3 dengan tema Ananda... Ayo ke Surga. Sementara Aulia No. 4 seolah melanjutkan isu yang dimunculkan pada edisi sebelumnya. Tema utama yang diusung dalam edisi ini adalah Remaja, Seks dan Cinta.Isu utama ini ditujukan kepada perempuan yang memiliki anak usia remaja. Dilatarbelakangi dengan fakta-fakta mengenai pergaulan bebas remaja.

Selanjutnya, narasi visual yang merepresentasikan perempuan Yakin Cerdas Bergaya sesuai dengan tagline Noor sebagaimana gambar 3.
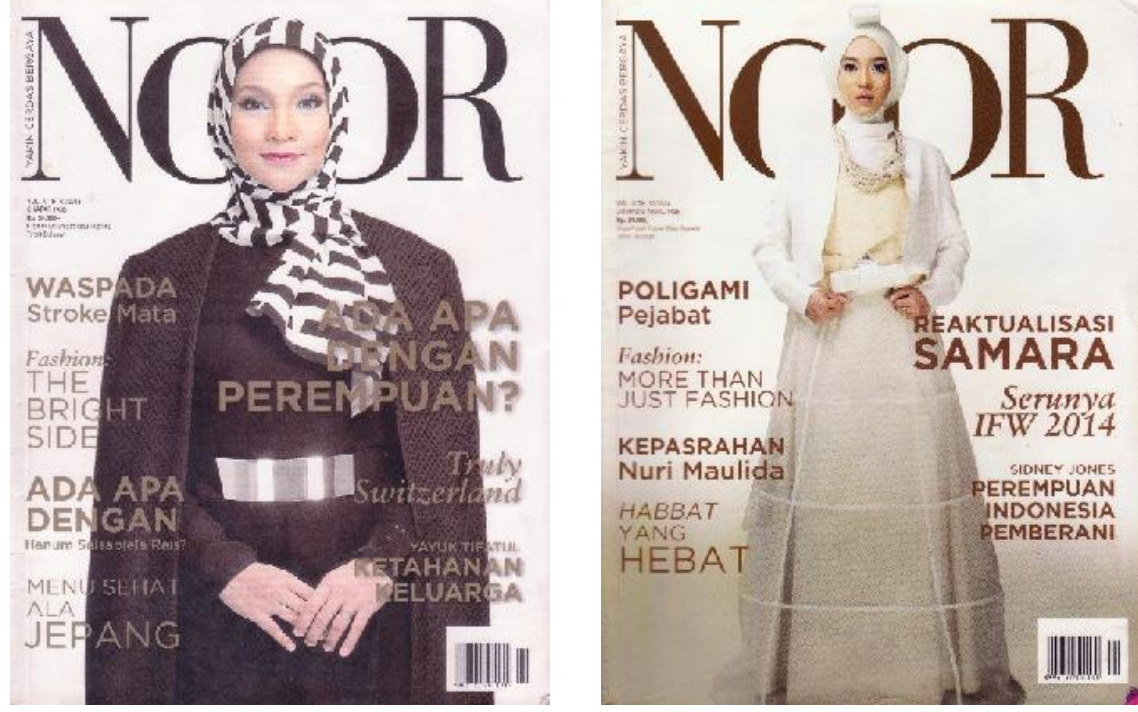

Gambar 3. Sampul Depan Majalah Noor

Sumber: Noor Vol.X/Th. XI/2013 SHAFAR 1435 dan Noor Vol.II/TH.XI/2014 JUMADIL AWAL 1435 
Berbeda dengan Ummi dan Aulia, Noor menampilkan perempuan sebagai sosok yang mandiri dan powerful berdasarkan pilihan petanda yang dilekatkan pada sampul depan tiap terbitannya. Perempuan yang dijadikan representasi ideal pada Vol. X diwakili oleh Hanum Salsabiela Rais penulis novel 99 Cahaya di Langit Eropa. Nama Hanum dituliskan di sampul depan, diwakili dengan caption Ada Apa dengan Hanum Salsabiela Rais? Nama Rais mengingatkan pada tokoh reformasi Amien Rais, ayah Hanum.

Sementara Noor Vol. II perempuan direpresentasikan oleh sosok Nuri Maulida yang berpose 'gagah' layaknya prajurit dengan ekspresi tegas. Diiringi caption Kepasrahan Nuri Maulida berkait dengan kisah hidupnya yang tidak jadi menikah untuk kedua kalinya. Paradoks antara kata pasrah dan pose pejuang yang ditampilkan oleh Nuri memunculkan gagasan mengenai pemaknaan kepasrahan sebagai perjuangan yang harus ditempuh perempuan ataukah ujung dari perjuangan merupakan kepasrahan kepada Tuhan

Berdasar narasi visual dari identitas perempuan (muslim) yang diartikulasikan, peneliti menyimpulkan bahawa interpretasi majalah terhadapnya tidaklah tunggal, melainkan plural dan dipengaruhi oleh banyak faktor termasuk modernisasi dan globalisasi dalam bentuk transformasi sosial (Williams, 1998:278, Thorpe, 2008). Setiap majalah mendefinisikan konsepnya masing-masing mengenai representasi perempuan ideal yang mewakili taglinenya. Hal ini konsisten dengan konsteksi diskursus Islam di Indonesia yang terbentuk atas beragam genre dan penafsiran.

\section{Kodrat Perempuan: Menjadi Istri Kemudian Ibu?}

Setelah membahas mengenai narasi visual identitas perempuan melalui sampul depan majalah, selanjutnya akan dibahas mengenai kodrat perempuan yang nantinya akan berkonsekuensi pada hak, kewajiban serta ranah yang dihabituskan pada perempuan. Bahasan pada bagian ini akan dipusatkan pada transformasi identitas perempuan terkait dengan manuskrip sosial yang biasa disebut sebagai 'kodrat'. Penggunaan terminologi kodrat dimaknai sebagai peran sosial yang tak terelakkan pada suatu identitas. Kodrat perempuan dibatasi pada transformasi identitasnya sebagai individu yang kemudian ber'kodrat' menjadi istri hingga berujung pada menjadi ibu. Pada dasarnya, konstelasi diskursus macam itulah yang tengah beroperasi pada kondisi Indonesia kontemporer.

Seperti yang telah digambarkan dengan jelas di sampul depan Ummi, perempuan digambarkan bersama dengan mukhrimya, suaminya. Diskursus keharusan perempuan untuk menikah dan berumah tangga diperkuat dalam Rubrik Cakrawala (Ummi No.5: hal.46) berjudul Perempuan "Melamar" Laki-Laki Bolehkah?. Narasi rubrik tersebut diawali dengan kisah Lala yang tengah gundah karena akan dijodohkan padahal ia sudah punya pilihan. Berlanjut, Lala akhirnya "melamar" lelaki pilihannya lewat pesan singkat dan direspon secara positif. Cerita diakhiri dengan narasi, "Lala tersenyum sumringah. Kisahnya pun berakhir indah."

Diskursus yang ditampilkan oleh Ummi ini betul-betul menarik, di satu sisi ia berusaha mengartikulasikan kebebasan perempuan untuk memilih pasangan hidupnya. Namun, paradoks menjadi muncul manakala artikel ini diakhiri oleh narasi, "Mana yang menjadi pilihan Anda, "dilamar" atau "melamar"?". Artinya, kebebasan dalam memilih pasangan merupakan kebebasan semu di dalam penjara pernikahan. Tak ada pilihan untuk tidak dilamar ataupun melamar. Pilihan hidup perempuan lantas menjadi jelas, dilamar maupun melamar ujungnya tetap sama, pernikahan dan menjadi istri. Kodrat identitas perempuan 
yang berawal dari anak ayahnya bertransformasi menjadi istri dari suaminya, tetap pada posisi subordinat.

Setelah menikah dan bertransformasi menjadi istri, diskursus kodrat yang diartikulasikan Ummi kembali mentransformasi identitas istri menjadi ibu, serupa dengan diskursus dominan di Indonesia kontemporer. Bahasan mengenai perempuan yang menjadi ibu diartikulasikan secara gamblang pada tiap edisi Ummi yang memunculkan sosok perempuan dengan anak pada gambar-gambar visual dalam majalahnya. Pada Ummi No. 5 kehadiran anak sebagai representasi interaksi seksual yang bersifat prokreatif menjadi Bahasan Utama dengan tema, Kompak Walaupun Belum Ada Anak, seperti yang ternarasikan berikut:

Belum adanya anak tak seharusnya merenggangkan, atau malah menjadi alasan lempar kecewa suami istri. Inilah sebetulnya waktu yang tepat untuk mempererat kedekatan dan menambah kekompakan berdua ... Upaya untuk meraih keselarasan dalam hubungan suami istri tergantung seberapa besar konsistensi sikap saling menghargai, menyayangi dan kepercayaan antarmereka. Sama sekali bukan bergantung pada ada atau tidaknya anak.

Sumber: Ummi No. 5 hal. 26

Artikulasi diskursus kesetaraan gender menjadi muncul pada ulasan tersebut. Tugas yang dibebankan oleh manuskrip sosial pada pasangan heteroseksual di Indonesia adalah hadirnya anak sebagai representasi fungsionalisme reproduksi dalam rangka meneruskan keturunan dan mewariskan nilai budaya. Artinya, belum atau tidak munculnya keturunan pada ikatan pernikahan tidak dideterminasi oleh kesalahan perempuan sebaga istri. Hal tersebut dinarasikan jelas pada rubrik tersebut.

Bahkan, bahasan utama berjudul Infertilitas di Atas Kertas (Ummi No.5: hal.18) dinarasikan bahwa kondisi tersebut muncul berdasar beberapa variabel, tidak hanya karena istri yang kerap muncul pada narasi dominan di Indonesia. Suami, kondisi lingkungan serta gaya hidup disinyalir dapat menjadi faktor determinan yang memunculkan infertilitas. Konter diskursus yang diartikulasikan Ummi menurut peneliti menunjukkan progresivitas promosi kesetaraan gender. Paling tidak, perempuan tidak lagi disalahkan dan dipaksa untuk berusaha sendiri dalam rangka menghadirkan keturunan. Kerjasama suami sebagai pasangan dinilai signifikan dalam rangka mewujudkan cita-cita prokreasi ini.

Namun, jika ditilik secara kuantitas, ada yang menggelitik dari bahasan belum munculnya keturunan ini. Penggunaan kata "belum" sebagai judul utama dapat dimaknai "akan ada" suatu saat nanti. Hal ini diperkuat dengan artikulasi diskursus "menanti" hadirnya keturunan yang dimunculkan pada delapan artikel dimana enam diantaranya menarasikan kehadiran keturunan setelah memasrahkan diri pada Tuhan, satu artikel masih menanti karena baru dua tahun menikah, sementara satu lainnya menarasikan disfungsi fisik akibat penyakit yang berujung pada aktivisme perempuan pada lembaga sosial. Artinya, apapun kondisinya, identitas perempuan yang sebelumnya telah bertransformasi menjadi istri akan berujung pada kodrat menjadi ibu. Karena "belum", maka suatu saat nanti akan "ada", kalaupun tidak mungkin maka perempuan tetap harus memenuhi fungsi ke"ibu"annya dalam bentuk apapun.

Sementara itu, Aulia yang disegmentasikan untuk perempuan yang telah menikah lebih memusatkan identitas perempuan sebagai ibu. Pernikahan yang menghasilkan keturunan diartikulasikan sebagai keniscayaan sehingga bahasan lebih diutamakan tentang bagaimana tanggung jawab perempuan sebagai ibu untuk anak dan keluarganya. Berbeda dengan Ummi yang menggunakan diskursus yang beredar di masyarakat untuk menarasikan isu-isu yang dibahasnya, Aulia menggunakan dogma agama untuk menelaah tiap isu dalam terbitannya. 
Sebagai istri, tugas utama perempuan adalah mengoperasikan aktivitas rumah tangga, Keikhlasan dalam membina rumah tangga sering disebut sebagai salah satu kunci mencapai keluarga sakinah, mawaddah, wa rahmah. Diskursus keikhlasan dalam mengoperasikan institusi rumah tangga sebagai seorang istri diresonansikan terus-menerus selama terbitan. Bahkan, hukuman untuk istri durhaka juga diartikulasikan dalam terbitan ini (Aulia No. 3: hal. 12). Kewajiban suami untuk memukul istri yang durhaka berdasar Al-Qur'an dan AlHadist dimunculkan. Walaupun, menurut Parvez (Engineer, 2007: 77) pemukulan yang ditafsirkan dalam QS. An-Nisa ayat 34 itu bukanlah pukulan dari suami pada istri melainkan pukulan yang diberikan kepada perempuan (tidak harus seorang istri) yang menentang hukum Allah.

Istri diposisikan sebagai "pemimpin" di rumah suaminya. Diskursus "pemimpin" ini ditafsirkan sebagai pelaku utama dalam ranah domestik. Aulia juga memunculkan kontra diskursus terhadap feminisme liberal (Aulia No. 3: hal. 14) yang dianggap "menyemangati" perempuan Islam untuk beralih dari fungsi domestiknya:

Globalisasi yang Merusak. Ironisnya, sementara Islam sudah mengatur tatanan kehidupan berkeluarga yang sempurna, sebagian masyarakat justru beralih pada ajaran Barat. Mereka beranggapan pemikiran negara-negara maju lebih hebat dan modern dibandingkan ajaran Islam yang dipandang kuno serta tradisional. Ya, mereka memang 'maju', tapi ke arah yang salah.

Menikah lalu menjadi seorang ibu, dalam konvensi CEDAW (Convention on the Elimination of All Forms of Discrimination Against Women) adalah sebuah ikatan yang membelenggu dan mereka mendorong anak-anak perempuan terlepas dari 'kekangan' ini. "Padahal dalam Islam, peran ibu sangat suci. Seorang ibu disebutkan berhak atas surga," tutur Kamilia.

Sumber: Aulia No. 03, hal. 16

Language is emotionally loaded (Burke dalam Littlejohn, 2000). Artikulasi diskursus yang dimunculkan dalam bahasa penuh emosi tersebut menarasikan ketidaksetujuan Aulia terhadap transformasi identitas istri dan ibu yang mengarah pada kesetaraan gender.

Lebih lanjut, gerakan feminisme 'barat' dianggap Aulia sebagai tipuan yang dilakukan oleh negara-negara maju. Sebagai konsekuensi, perempuan yang mengikuti arus diskursus tersebut akan merusak fitrahnya sebagai istri dan ibu yang berimplikasi pada rusaknya aturan pola asuh anak dan berujung pada mendekatkan anak pada perzinahan (Aulia No. 3: hal. 1618). Sehingga, Aulia menyarankan para perempuan untuk kembali kepada identitasnya sebagai istri dan ibu sesuai yang digariskan oleh Al-Qur'an dan Al-Hadist sesuai dengan tafsiran mereka. Maka dari itulah edisi kali ini membahas mengenai kewajiban ibu untuk menjalankan fungsinya sebagai 'pengajak' anak ke surga.

Berdasarkan pemikiran dalam edisi tersebut, Aulia memutuskan untuk meresonansi diskursus ini pada edisi selanjutnya dengan sasaran dakwah baru, anak usia remaja. Rubrik Aulia Utama yang berjudul Remajaku, Belajarlah Cinta, Belajarlah tentang Seks (Aulia No. 4: hal. 56) dibuka dengan narasi sebagai berikut:

Aborsi, Seks bebas. Film dan games porno. Pacar dan cinta. Siapa saja yang hidup bersama atau berdekatan dengan remaja masa kini akan sadar, the true horror and terror adalah ketika kita dapati aqidah dan akhlaq mereka hancur karena setan berhasil menjual 'dagangannya' yang bernama: Cinta.

Bahasan utama tersebut mereproduksi artikulasi diskursus tugas perempuan sebagai ibu untuk mendidik anaknya dan menjauhkan mereka dari 'siksa api neraka'. Bahasan yang (awalnya) menarik perhatian peneliti karena memasukkan terminologi 'seks' yang biasa dihindari oleh majalah perempuan muslim ternyata tidak memiliki muatan seksual sama 
sekali. Dipenuhi dengan dalil-dalil dari Al-Qur'an dan Al-Hadist, bahasan tersebut ditutup dengan narasi, "Sesudah belajar tentang Allah, tentang penghambaan kepadaNya, tentang rasa malu, lalu tentang rasa cinta, maka Insya'Allah kita dan remaja siap belajar tentang seks!"

Satu hal yang menarik bagi peneliti dalam bahasan Aulia dua terbitan ini, tugas mendidik anak yang dibebankan sepenuhnya pada perempuan. Pun absennya kehadiran anak laki-laki sebagai ilustrasi diskursus pada dia terbitan tersebut. Pengaturan terhadap perempuan sebagai ibu untuk mengatur anak perempuanya sebagai calon istri dan ibu menjadi satu-satunya diskursus utama yang mengalir pada ulasan Aulia (No. 4: hal. 42-76). Mulai dari mengatur memilih Bra (hal 42-46), menjaga aurat dan memperlakukan tubuh dengan hormat (hal. 5663), mengatur pilihan teman (hal. 64-71), hingga belajar beladiri untuk melindungi diri sendiri (hal. 72-76) semuanya ditekankan sebagai kewajiban anak perempuan.

Berbeda dengan dua majalah sebelumnya yang secara konsisten menarasikan kodrat tak terelakkan perempuan sebagai istri kemudian ibu, Noor tidak terlalu dipusingkan dengan permasalahan tersebut. Isu-isu yang dimunculkan dalam Noor tidak berkutat pada teknik terbenar sesuai dalil bagi perempuan untuk menjalankan kewajibannya sebagai istri dan ibu, melainkan pada isu-isu memberdayakan perempuan (yang juga) sebagai khalifah di muka bumi. Secara visual, Noor menggambarkan perempuan sebagai subjek yang berdiri sendiri tanpa kehadiran objek lain (laki-laki atau anak kecil) guna melengkapi identitasnya.

Meski reproduksi diskursus identitas perempuan sebagai istri dan ibu tetap dimunculkan, namun kemunculannya tidak signifikan. Pada artikel Quo Vadis Budi Pekerti (Noor Vol X: hal. 78) yang membahas mengenai dekadensi moral generasi muda, memberikan solusi pemberdayaan perempuan terlebih dahulu. Sebelum menjalankan fungsinya sebagi ibu, perempuan diharuskan untuk belajar dan memberdayakan dirinya dahulu guna mencetak generasi muda yang baik. Poin utama yang bisa disarikan dari diskursus ini mengenai pencapaian pribadi perempuan sebagai subjek identitas lantas menjadi lebih mutlak dibandingkan memusingkan menjalankan kewajiban sesuai dengan dalil (Hefni, 2006).

Noor juga menampilkan diskursus kodrat-kodrat alternatif yang bisa dipilih perempuan selain menjadi istri dan ibu, menjadi politisi misalnya (Noor Vol II: hal. 24-25). Perempuan pebisnis juga diartikulasikan diskursusnya melalui artikel Pentingkan Nilai Halal dan Thayibah (Noor Vol II: hal. 48-50) yang mengusung tiga perempuan pebisnis kuliner Indonesia dimana sepanjang artikel tidak pernah menarasikan kehidupan pribadi mereka sebagai istri maupun ibu namun lebih menceritakan usaha keras mereka hingga mencapai titik keberhasilan.

Dialektika diskursus kembali muncul pada pembahasan di bagian ini. Setiap majalah menawarkan kodrat pada identitas perempuan dengan caranya masing-masing. Aulia dan Ummi cenderung mereproduksi diskursus istri dan ibu sebagai kodrat tak terelakkan dari perempuan sebagai subjek identitas. Sementara itu, Noor menawarkan tafsiran alternatif pada kodrat yang diemban perempuan dengan memberikan porsi lebih pada pemberdayaan diri dan berusaha keras pada jalan hidup yang telah dipilih tanpa mengindahkan posisi pribadinya sebagai istri maupun ibu.

\section{Kontestasi Ranah: Domestik vs Publik}

Selanjutnya, bahasan akan diteruskan pada konsekuensi dari bahasan sebelumnya mengenai kodrat, yakni ranah. Terminologi ranah digunakan dalam definisi lokasi sosial yang ditempati perempuan untuk mengartikulasikan identitasnya. Diskursus yang telah 
ditetapkan oleh para ulama ortodoks dan konservatif muslim terkait dengan ranah perempuan, dibatasi secara ketat di rumah. Hal ini muncul sebagai konsekuensi tugas utama perempuan untuk menjaga suami dan anak-anaknya (Engineer, 2007: 265, Kim, 2014). Melalui bahasan bagian ini peneliti akan mengeksplorasi artikulasi diskursus ranah, apakah masih direproduksi atau malah telah didekonstruksi.

Ummi mengartikulasikan diskursus ranah yang didiami perempuan tidak lagi dalam posisi dikotomis antara memilih ranah domestik atau publik melainkan bisa dijalankan bersamaan. Bahasan Bekerja sebagai Ladang Ibadah (Ummi No. 4: hal.12) menarasikan perempuan yang mengaktualisasikan dirinya pada ranah publik. Narasi ini diresonansikan berulang dalam majalah (Ummi No. 4 hal. 14-16, 28, 52, 86. Ummi No. 5 hal. 12, 14-16, 30, $52,86)$. Bentuk-bentuk aktualisasi diri di ranah publik antara lain berprofesi, menghasilkan uang, terlibat dalam aktivitas sosial hingga menjadi perempuan berprestasi yang diakui oleh publik.

Walaupun diskursus perempuan di ranah publik diresonansikan berulang kali, namun peletakkan perempuan dalam ranah domestik turut hadir bersamaan dengan hal tersebut. Tanggung jawab perempuan yang utama untuk mengoperasikan rumah tangga sebagai ranah domestik masih menjadi diskursus dominan. Narasi seperti, "Apa yang Ninit lakukan membuktikan bahwa berada di rumah tak menghalangi perempuan untuk berkarya. Bagaimana dengan Anda" (Ummi No. 5: hal. 16) yang meletakkan posisi utama perempuan dalam ranah domestik juga turut direproduksi dalam diskursus teks.

Meski posisi perempuan yang utama dinarasikan berada di ranah domestik, namun diskursus kesetaraan gender atas relasi perempuan dan laki-laki dalam ranah domestik turut diproduksi dalam teks Ummi. Pembagian tugas domestik yang seimbang antara suami dan istri (Ummi No. 4: hal. 30, 81, 86) serta kesadaran suami untuk mendukung istri dengan membantunya di rumah (Ummi No. 5: hal. 12, 27, 28) mengartikulasikan perspektif kesetaraan gender antara perempuan dan laki-laki. Artinya, identitas perempuan yang diartikulasikan Ummi tidak membatasi ranah perempuan di ranah domestik namun memberikan tempat baginya untuk mengaktualisasikan dirinya di ranah publik walaupun tetap mengoperasikan ranah domestik dengan bantuan pasangan.

Jika Ummi berusaha mempromosikan kesetaraan gender dengan mengartikulasikan diskursus tampilnya perempuan di ranah publik diiringi dengan keseimbangan pembagian tugas domestik bersama suami, maka Aulia berusaha mengembalikan perempuan untuk bertanggung jawab penuh pada ranah domestik. Walaupun diskursus perempuan yang tampil di ranah publik turut dimunculkan namun skala pengartikulasiannya tidak sigifikan baik secara kuantitas maupun kualitas (Aulia No.3 : hal. 122, No.4: hal. 18, 22). Aulia menggarisbawahi bahwa kerusakan generasi muda merupakan implikasi dari terlalu seringnya perempuan berkarya di ruang publik.

Maka dari itu, posisi perempuan dikembalikan kepada 'kodrat' ranahnya yaitu di ruang domestik, di rumah menjaga keluarga dan anak-anaknya. Diskursus konservatisme Islam direproduksi oleh Aulia terkait dengan pembatasan ranah perempuan di ruang domestik disertai dalil-dalil dan konsekuensi negatif yang akan muncul jika ruang domestik diacuhkan oleh perempuan. Konsisten dengan sampul depan majalah, artikulasi diskursus kebebasan perempuan secara konsisten dimunculkan oleh Noor. Nyaris tidak ada pergulatan dalam rangka migrasi perempuan dari ranah publik ke domestik maupun sebaliknya. Noor mengartikulasikan migrasi tersebut sebagai keniscayaan yang mengalir. Walaupun tidak bisa dinafikkan, nilai lebih diberikan Noor pada perempuan yang sukses di ranah publik, maka dari itu, bukannya lebih banyak membahas mengenai isu-isu perempuan beserta dalilnya 
seperti yang dilakukan oleh Aulia, Noor lebih menghadirkan tokoh-tokoh perempuan yang dianggap inspirasional dengan pencapainnya di ruang publik (Noor Vol X: hal. 12, 18-19, 58-59, 66-67, 68-71, 78-79, 86-88, 110-127; Nooer Vol II: hal. 9, 16-17, 20-21, 24-24, 48$50,51-53,80,82-84,87-89,93-95,116-117,118-119,122-128)$

Mudahnya migrasi antar ranah ini diilustrasikan Noor (Vol X, hal. 70) melalui tokoh Sri Rahayu Purwitaningsih, mantan anggota DPRD, istri mantan Menkominfo Tifatul Sembiring dalam artikel yang diambil dari kutipan kata-katanya, "Perempuan juga Khalifatullah" yang jika diartikan secara literal bermakna perempuan juga merupakan pemimpin yang ditunjuk oleh Allah.

Tak hanya berbicara soal kemuliaan perempuan di mata Islam, Yayuk - tanpa bermaksud riya - berbagi soal pengalamannya mengelola secara hermonis kehidupan pribadinya. Terutama menyangkut perannya di dua ranah tersebut: ranah domestik dan ranah publi. Menurutnya, amat penting harmonisasi itu dijaga dan diterapkan dalam rumah tangganya. Perannya di ranah domestik dan publik dijalani sebagai upaya melaraskan kehidupan dalam rangka ketahanan keluarga.

Noor menggunakan terminologi 'mengelola secara harmonis kehidupan pribadinya' dan bukannya menggunakan kata keluarga menyiratkan diskursus kemandirian serta kebebasan pada diri perempuan. Kalaupun perempuan berkarya pada kedua ranah bukanlah hal yang patut dipermasalahkan jika ia memang secara sadar memilih demikian. Penggunaan terminologi Khalifatullah untuk merepresentasikan perempuan juga makin memperkuat artikulasi diskursus kebebasan dan kemandirian pada identitas perempuan.

Akhirnya, bisa disimpulkan jika masih terdapat dialektika pada kontestasi ranah yang didiami oleh identitas perempuan. Aulia yang menyuratkan reproduksi diskursus dalam konteks mendikotomikan ranah perempuan memberikan pilihan akhir ranah domestik guna menyongsong kemuliaan yang ditawarkan oleh Tuhan. Sementara itu, Ummi mengakomodasi artikulasi identitas perempuan dalam ranah domestik maupun publik dibumbui diskursus kesetaraan gender yang turut membebankan kepengurusan ranah domestik pada laki-laki. Sementara Noor memberikan diskursus keutamaan perempuan untuk berkarya dan berprestasi di ranah publik.

Hal ini konsiten dengan pernyataan Blackburn (2008:4) dan Schroder (2007) mengenai interpretasi keislaman yang terartikulasikan dalam artefak budaya maupun perilaku manusia Indonesia yang beragam sesuai dengan konteksnya. Satu hal yang perlu diingat bahwa Islam yang ada di Indonesia berbeda dengan dengan Islam yang ada di Arab. Begitu banyak akulturasi budaya yang dipraktikkan masyarakat Indonesia dalam kesehariannya sehingga menyebabkan pendefinisian syari'at Islam serta praktiknya pun menjadi berbeda.

\section{KESIMPULAN DAN SARAN}

Berdasarkan pembahasan yang dilahirkan dari proses eksplorasi pada majalah-majalah perempuan Muslim menggunakan kacamata konstruktivis dan feminisme liberal dapat diambil kesimpulan bahwa identitas perempuan (muslim) Indonesia bukanlah suatu hal yang mutlak. Walaupun secara dogma diangkat dari kitab suci yang sama, namun tafsiran terhadap pengartikulasikan identitas perempuan beserta kodrat dan ranah yang mengikutinya menjadi plural, saling berdiskusi bahkan saling mendebat.

Narasi visual dari ketiga majalah yang dijadikan sumber data menggambarkan dialektika diskursus yang mengartikulasikan identitas perempuan sebagai subjek. Majalah Ummi cenderung meletakkan identitas perempuan sebagai istri yang berkonsekuensi pada 
munculnya suami dalam setiap sampul depan majalah. Sementara Aulia lebih menekankan pada permainan tanda untuk menggambarkan isu-isu yang tengah dihadapi perempuan dalam rangka menjalankan fungsi tak terelakkannya sebagai istri dan ibu. Sementara Noor memvisualisasikan perempuan sebagai individu yang mandiri, bebas serta tegas melalui sampul depannya yang memunculkan perempuan dengan ekspresi dan pose yang powerful.

Konstelasi diskursus dominan dalam kerangka negara yang berlandaskan patriarkhi masih direproduksi oleh Aulia dan Ummi melalui artikel-artikelnya. Kodrat perempuan sebagai istri dan ibu menjadi suatu keiscayaan yang harus dilaksanakan secara fungsional. Diskursus kesetaraan gender diartikulasikan oleh Ummi melalui jalinan tanda yang melibatkan laki-laki dengan beban kerja yang sama dengan perempuan dalam urusan domestik. Sementara itu, Aulia menggunakan dalil-dalil dari kitab suci dan hadis untuk melegitimasi teknik-teknik terbenar bagi perempuan untuk menjalankan kewajibannya sebagai istri dan ibu. Gagasan ini lantar dikontraskan oleh Noor yang menawarkan alternatif kodrat perempuan dengan menganihiliasikan terminologi istri dan ibu manakala membahas mengenai pencapaian seorang perempuan.

Kontestasi pada ranah yang digunakan perempuan untuk mengaktualisasikan dirinya juga seolah meresonansikan kemunculan dialektika diskursus. Dikotomi ranah publik dan domestik masih direproduksi oleh Aulia yang berujung pada pembatasan wilayah perempuan di ranah domestik. Sementara Ummi sudah menghapuskan garis dikotomi dengan mengartikulasikan diskursus bahwa perempuan dapat berkarya dan berprestasi dalam ranah publik namun tetap dalam kerangka tanggung jawab penuh terhadap pengoperasian ranah domestik. Noor justru memberikan nilai lebih kepada perempuan yang memberikan prioritas pada ranah publik sehingga mampu memberdayakan dirinya dan menjadikan keberhasilannya sebagai inspirasi bagi perempuan (muslim) lainnya.

\section{DAFTAR RUJUKAN}

Aulia No.03Tahun X Syawal-Dulqo'dah 1433/September 2012

Aulia No.04 Tahun X Dzulqa'dah-Dzulhijjah 1433/Oktober2012

Blackburn, S. Smith, B.J. and Syamsiatun. S., (Ed). 2008. Indonesian Islam in a New Era; How Women Negotiate their Muslim Identities. Clayton: Monash University Press.

Engineer, A.A. 2007. Pembebasan Perempuan. Jogjakarta: Penerbit LKiS.

Fiske, J. 1996. “Communication, Meaning and Sign”.Dalam Introduction to Communication Studies. Routledge: London.

Foucault, M. 2012. Arkeologi Pengetahuan. Jogjakarta:IRCiSoD

Hall, S. 2002. "The Work of Representation". Dalam Representation; Cultural Representations and Signifying Practices. Sage Publication: London.

Hefni. Moh. 2006. Tirani Kekuasaan dalam Sirkulasi Teks; Menelaah Pemikiran Arkeologis. Jurnal KARSA Vol. IX (1). Hal 863-870

Hollows, J.2000. Feminisme, Femininitas, dan Budaya Populer. Yogyakarta: Jalasutra.

Ibrahim, I.S. 2007. Dunia Simbolik dan Gaya Hidup dalam Beragama: Dari Ideologisasi ke Komersialisasi Spiritualitas. Bandung: Jalasutra.

Keller, M. and Halkier, B. 2013.Positioning Consumption: A Practice Theoretical Approach to Contested Consumption and Media Discourse, Marketing Theory, 14, pp. 35-51.

Kellner, D. 1995. Media Culture. Routledge: New York.

Kim, K. H. 2014. Examining US news media discourses about North Korea: A corpus-based critical discourse analysis', Discourse \& Society, 25, pp. 221-244. 
Littlejohn, S.W. (2000). Theories of Human Communication. Wasdworth Publishing: London.

McLaughlin, L. 2000. The Language of Magazines. Routledge: New York.

McQuail, D. 2000. "Theory of Media and Theory of Society". Dalam Mass Communication Theories. Sage Publication: London.

Mudhoffir. A.M. 2013. Teori Kekuasaan Michel Foucault: Tantangan bagi Sosiologi Politik. $\begin{array}{lllllll}\text { LabSosio } & \text { FISIP } & \text { UI, } & \text { Vol } & 18 & \text { (1). } & \text { url = }\end{array}$ http://journal.ui.ac.id/index.php/mjs/article/view/3734

Noor Vol.II/TH.XI/2014 JUMADIL AWAL 1435

Noor Vol.X/Th. XI/2013 SHAFAR 1435

Schroder, K. C. and Phillips, L. 2007. Complexifying Media Power: A Study of The Interplay Between Media and Audience Discourses On Politics', Media, Culture \& Society, 29(6), pp. 890-915.

Strinati, D. 2007. Popular Culture: Pengantar Menuju Teori Budaya Populer. Penerbit Jejak: Bandung.

Thorpe, H. 2008.Foucault, Technologies of Self, and the Media: Discourses of Femininity in Snowboarding Culture, Journal of Sport \& Social Issues, 32(2), pp. 199-229.

Ummi No.4/XXXIV/April2012/1439H

Ummi No.5/XXIV/Mei2012/1433H

Williams, L. 1998. Wives, Mistresses and Matriarchs Asian Women Today. Allen and Uwin: Sydney. 